\title{
Boreczky Ágnes \\ AZ ORKESZTIKA TUDOMÁNYOS RENDSZERE ÉS A PEDAGÓGIA DIENES VALÉRIA KORAI MUNKÁSSÁGÁBAN
}

DOI: https://doi.org/10.32558/abszolut.2021.12

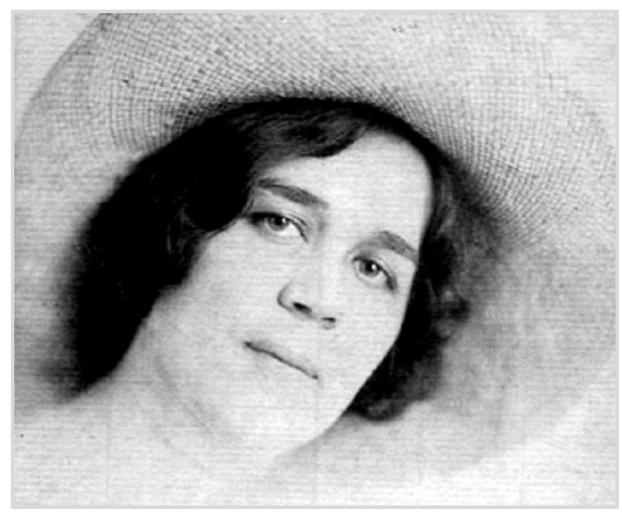

Dienes Valéria (1879-1978)

Márknak a „túlsó partról’l

„Mert az ember léte csupa alkotás. Apróbb vagy nagyobb. Úgy fejlödik mindegyik, mint valami élölény. Ugyanúgy, mint akár mindenestül önmagunk. [...] Születnek, élnek és meghalnak (olykor nem halnak meg velünk együtt). Igy az orkesztika elsö halk igéretének [...] a pillanatában már együtt voltak a kellékek az induláshoz: az egyetemi években szerzett tudományos és filozófiai kultúra, a zeneakadémián elsajátitott zenei készültség, új matematikai tételeken csiszolódó alkotói gyakorlat, és [...] belépett egy új jövevény, a mozdulat, és nem lebetett tudni róla, mit akar. Meg kellett barátkoznom vele. Izomzatomban hoztam haza 1912 nyarán." (DIENES 1969, 17-18.)

A fenti idézet 1969-ből való ${ }^{2}$ Néhány évvel később viszont, 1975-ben, egy Vitányi Ivánnak ${ }^{3}$ adott interjú előtt írt feljegyzéseiben Dienes Valéria

\footnotetext{
${ }^{1}$ A tanulmány szerzője írását a mű keletkezése idején - megrendítően fiatalon elhunyt - tehetséges tanítványa és kollégája, Fenyves Márk emlékének ajánlotta.

2 Dienes Valéria (1969): Orkesztika 1912-1918. Raymond DunCANNÁL, dvh-list00043 MOHA Mozdulatmüvészeti Gyüjtemény (Orkesztika Alapítvány - MOHA - Mozdulatművészek Háza Magángyủjtemény, a továbbiakban MOHA)
} 
ugyanerre az időszakra másként emlékszik vissza: „Párizs, Bergson, a Collège de France órái megmaradtak egész életemre. Megijedek, milyen tarka ember voltam." (DiENES 1974-76, o. n.)

Az interjú felvételekor Dienes Valéria 96 éves volt, a mondat életének az emigrációt megelőző szakaszára vonatkozik. Melyik állítást, melyik képet tartsuk mérvadónak? Azé a fiatal nőét, akit később, visszatekintve ifjúkori önmagára kialakulatlannak, esetleg zavarosnak láthatott, vagy azt a mottóból is kitűnő ihletett és izgatott készülődést, aminek - ma már tudjuk -, az orkesztika lett az eredménye.

A jelenből visszanézve az említett időszak Dienes életének legmozgékonyabb, egyben egyik legtermékenyebb időszaka ${ }^{4}$. Ekkor született két fia, Gedeon és Zoltán, számos tanulmánya jelent meg a Huszadik Században, $A$ Nő és $A$ Gyermek c. folyóiratban, előadásokat tartott a Gyermektanulmányi Társaságban, A Társadalomtudományok Szabad Iskolájában és a Feministák Egyesületében, s nem utolsó sorban ezekben az években dolgozta ki az orkesztika rendszertanát. A sokféle, látszólag eltérő, de mai szemmel és az életmű egésze felől egységet alkotó tevékenységet Dienes négy szerelme, a matematika, a filozófia, a zene és az orkesztika iránti mély (később sem szűnô) elkötelezettsége füzi össze. És még valami: az orkesztikába beépülve, annak fundamentumában egyaránt helyet kapott Dienes matematikai, filozófiai, zenei, valamint pszichológiai tudása. ${ }^{5}$ A többféle tudomány és a múvészet összekapcsolásával megalkotott rendszer, a „tudós táncosnő” image-ban feloldott szerepkonfliktus megoldásának más európai táncosokhoz képest is rendkívüli útja a hazai mozdulatmúvészeten belül mintateremtővé vált.

Közismert, hogy Dienes Valéria - a Magyarországon elsőként egyetemet végző nők egyike - matematikus és filozófiai doktor, aki egyetemi tanulmányi közben a Zeneakadémiát is elvégezte. Filozófiai doktori disszertációja (1905) és a bécsi emigráció közti időszakban $23^{6}$ tanulmányát említi (lásd a Függelékben), jelentékeny részük már sokirányú pszichológiai tájékozódását jelzi. Bár ezektől

\footnotetext{
${ }^{3}$ DiEnES Valéria ( 1974-1976): Életrajæi vázlatok, Kézirat. EDAR DVH-rendezetlen spirálfüzet - még leltári szám nélkül - MOHA

4 Át- és újragondolva életének a tanulóéveket követő első szakaszát 1912 és 1917 közé datálta és spirálfüzetében a következőképpen összegezte:

1. $1912-1917,1914-$ Gedeon, 1916 - Zoltán

2. orkesztika, gyermeklélektan, Huszadik Század, Társadalomtudományi Társaság, Galilei Kör

3. Szülők Iskolája, Nagy László, Domokosné iskolája, ahova fiaim járnak (Dienes gyerekei 20-as években, az emigrációt követően jártak az Új Iskolába- BÁ)

4. előadások

${ }^{5}$ Errôl részletesen ír a kötet egyik tanulmányában Benedek András.

${ }^{6}$ A Nö́ben és A Gyermekben megjelent tanulmányait nem sorolja fel.
} 
elválaszthatatlan, szempontunkból most fontosabb Dienes Valéria mozdulattudománya, ami egyfelől önálló pedagógiai rendszernek is tekinthető, másfelől múvészi vonatkozásait (mûvészi nevelés) tekintve a pedagógia része (DIENES 1925-26., 2016, 434).

Jelen írásban, ha vázlatosan is, erre az összefüggésre irányítom a figyelmet.

\section{A mozdulattudomány}

Dienes mozdulattudománya európai szinten is igen korai, és talán nem túlzás azt állítani, hogy az első interdiszciplinárisan megalapozott tudományos rendszer. Ez a mozdulattudomány tulajdonképpen maga a teljes orkesztika. „Amit ma táncnak neveznek, és tánc néven mutatnak, az. parányi elfajult töredéke, kis elszántott része egy nagy müvészet-mezönek, a mozdulatok müvészetének, a régi, valamikor nagy, intenziv életet élt orchesztikának." - írja 1918 januári levelében Hans Brandenburgnak.7 (DIENES 1918, 2016,)

A későbbi, Orkesztika 1912-1918 c. írása szerint magába foglal mindennemű „mozdulattudományi fejezetet, balettet, sportokat, gyógytornát, néptáncot, dzsessztáncot, transz-táncot, katonai kiképzést..." (DIENES 1969, 43.), vagyis mindent, ami az emberi test mozdulattörvényeinek megismerését és betartását feltételezi. „Nem táncot akartunk, ez a fogalom túl szük volt. A táncnál valami általánosabbat, és a valóságos élethez közeledöbbet kerestünk, a mozdulattörvények által mesterséges kényszereitöl felszabaditott emberi test szabad játékét, amelynek beleszólása van minden (kiemelés B.Á.) emberi tevékenységbe." (DIENES 1969, 43-44.)

Dienes a már idézett, Hans Brandenburgnak írt levelében említi először, hogy készen áll saját orchesztikai (később orkesztikai) rendszere ${ }^{8}$, illetve a mozdulatok lejegyzésére kidolgozott orcheografia. ${ }^{10}$ (A levélből az is kiderül, hogy a rendszertan alapján az akkor már második éve múködő Orkesztikai Iskola szervezetét is kialakította.)

\footnotetext{
${ }^{7}$ Brandenburg Der moderne Tanz c. könyve volt az első olyan mű, mely a korabeli modern tánc irányzatait összegezte. Lásd részletesebben BORECZKY - FENYVES (2017) írását.

${ }^{8}$ A rendszer rekonstruálására nem áll rendelkezésre az a korabeli kézirat, amire a levél utal. Dienes ugyanakkor részletes leírást ad a levélben, és egy 1929-re datált kézirat sem állhat még nagyon távol az eredetitől. (Dr. Dienes Valéria orkesztikai rendszere a-dvh-list00002 MOHA.) De felhasználtam még néhány más, relatíve korai írását is. (pl. Bergsonizmus az iskolában, 1924- Pedagógiai-jegyzet, 1925-26Mozdulatkultúra, 1930.)

${ }_{9}^{9}$ Az orcheográfia közös munka eredménye volt, amiben a tanítványokon kívül Detre Szilárd és Dienes Pál is részt vett. Dienes a levélben megjegyzi, hogy a mozdulatírás feltétele a mozdulat-elmélet.

${ }^{10}$ Fügedi (2013) szerint a 20. században több tucat táncírás született, ezek közül Rudolf von Labané terjedt el a leginkább. (Sokan őt tekintik a táncírás megalkotójának.)
} 
A szűkebben értelmezett, Dienes által kimunkált és megvalósított orkesztika, akár a többi európai modern tánc (Ausdrucktanz, Bewegungstanz, free dance, mozdulatmúvészet stb.) új múfaj, a fien de siècle mûvészeti megújulásának része. ${ }^{11}$

Alappillérei a mozdulat, az eszmélet, a tér és az idő, az erő és a jelentés. Pszichológiájában Dienes a korabeli kísérleti pszichológiai eredményeire és Bergson filozófiájára támaszkodva az emberi viselkedést (cselekvés-reflexek - v.ö. behaviorizmus) és az eszméletet (eszmélettan) köti össze, ezek között a mozdulat a híd. Pedagógiájának kulcsszavai a felfedezés-alkotás-teremtés-cselekvés, a reformpedagógiából ismertek, kiemelendő azonban, hogy tudásnak csak az átlényegített személyes tudást tekinti, melyhez kizárólag az átélt tapasztalatokon és az azonosuláson keresztül juthatunk el. Bármelyik megközelítést helyezzük középpontba, a MOZDULAT szüntelen szemünk elénk kerül. Mozdulatrendszerről, és mozdulattanulmányról lévén szó, ez nem lenne meglepő, de a korabeli irányzatok egy részénél ez koránt sincs így (v.ö. Dalcroze euritmikája vagy Mensendieck női tornája stb.).

\section{Mozdulat - eszmélet és pedagógia}

„A mozdulat az eszmélés üzenete, mozdulat minden eltökélésünk, tettünk egész tudatos, sqándékos életünk. A gesztusok szavaink elöpostái és kíséröi, az arckifejezések, testtartások, tagjártatások, hangulatunk birnökei, mozdulat a létünk bordozója. (kiemelés B. A.) A tisztán az időben rejtörött anyagtalan lelkiségünk a mozdulaton át a térbe költözik, hogy megmutasson bennünket egymásnak.

A mozdulat nem másolja, hanem kifejezi a lelket azzal, hogy formát ad eszmélésünknek." (DIENES 1929a, 2.)

Dienes elméletének kiindulópontja a mozdulat(élmény) valósága. A „szómögöttiség” be vivő mozdulat az eszmélet testi kifejezése, megtestesülése, matéria és szellem, mely magában hordozza a múltat, a jelent és a jövőt. A múlt és a jelen az emlékezetben ér össze, és „a múlt nem tud másképpen ténylegesedni, mint annak a mozgástartalomnak útján, mely élménykorában része volt." (DIENES 1929a, 8.) A mozdulat kimunkálásának célja tehát nem a test, hanem a mozdulatot indító és az arra visszaható eszmélet ${ }^{12}$, ezért a mozdulattudomány számára nem elégséges az anatómiaismeret, vagy az ezek alapján történő testi fejlesztés. (DIENES 1929a).

\footnotetext{
11 „Ilyen új valóság a mozdulatmüvészet [...]. A mozdulatmüvészet nem torna és tánc, nem balett és nem sport, nem is ritmikus, nem is ritmustalan torna, nem is testhigiénia, sem gyakorlati egéssségtudomány, hanem a fejlödésnek új produketuma, mely a mai létfokán már külön kategóriát s ennek megfelelö elbirálást követel." (DIENES 1929b, 1.) 12 Már a hetvenes években írt munkáiban ezt a folyamatot a szimbolizáció és a szublimáció fogalmaival írja le. „A mozdulat az eszméletet szimbolizálja. Az eszmélet a mozdulatot szublimálja. A szimbolizálás szellemtől anyag felé, a szublimálás anyagtól szellem felé.” „(DIENES 1970 körül, 2017, 109.)
} 
Dienes felfogásában a mozdulat univerzális (minden ember sajátja), így minden mozdulatrendszer alapját csak a megismert mozdulattörvények alkothatják. S mert ez a Raymond Duncantól 1912-ben „izmaiban hazahozott” görög mozdulatkincs „az emberi test emelő-rendszerének egyensúlyi és elmozdulás-lehetőségeit" használja fel, mindenki számára természetes, gyakorlása nemcsak örömmel jár, az öneszmélésnek és önkifejezésnek is forrása.

A pedagógiai nyelvére lefordítva ez a következőt jelenti:

„A mozdulatcentrumos pedagógia oly mozdulati nevelést kiván, melyben a test nem önmagáért, hanem a mondanivalójáért válik acélossá és hajlékonnyá. A mozdulat igazi lélek.közege akar lenni, oly öntudatos pszichikai kifejezó es₹köz, mely a tanitásban módszerek hordozójává válhatik. A mozdulat e jelentéstani oldalának kifejlesztése nem puszta többlet, amit úgy egyszerüen hozzá lebetne adni egy tetszölegesen megadott izomkultúrához, hogy annak fizikai úton termelt gyümölcseit most a pszichikum számára értékesithessük. E jelentéstani igényeknek vissza kell hatniuk a test formális képzésére, érthetö ugyanis, hogy más mozdulatanyaggal fogom képezni a testet, ha tudom, hogy belöle mindenre érzékeny kifejezó" müsz̨ert akarok késziteni, melynek versenyezni kell a šóval, sốt túllépni a sæó határain, mint akkor, ha nem kivánok töle egyebet, mint a jól járó gép ruganyosságát.

E₹ nem azt jelenti, hogy az új pedagógia sqínpadra nevel. A barmonikus, sqép, tiszta mozdulat nem arra való, hogy az élet közege legyen, bogy közlekedésünk. természetes hidjául szolgáljon, hogy összebálózzon bennünket társainkekal. A helyes és ezzel egyszersmind szép mozdulat nem volna a legelemibb kötelességünk, magunk és az emberek iránt. A mozdulatok harmóniája általános kötelesség (kiemelés-B.Á.), nem árulni való kiváltság. A mozdulatnak igy be kellene bálózni életünket s mint a görög kultúrában, bevonulni társadalmi és egyéni létünk minden fázisába, mert egészséges, harmonikus élet e nélkül nem képzelhetō el. Tehát nem szinpadra, sem házi szinészkedésre kivánjuk a mozdulatot, amikor egy minden tanitást átjáró testkultúrát sürgetünk, hanem a mozdulat határtalan értékeit ki akarjuk szabaditani a színpad légköréböl és odaadni minden emberi életkornak, minden társadalmi rétegnek és visszaállitani azt az ốt megilletö helyre mindenekelött az emberképzzés terén." (DIENES, 1929a, 10.)

A mozdulatok harmóniájának kialakítása tehát az, ami a pedagógia (egyik) területe, és amit mindenki számára származástól és életkortól függetlenül biztosítani kéne. Ugyanakkor a mozdulat harmóniájának általános morális kötelességként való megfogalmazása, valamint szembeállítása a funkcionalitással, némiképpen ellentmond annak az állításnak, miszerint a mozdulat révén megmutatkozunk egymásnak, vagyis kommunikálunk egymással. 
Bár Dienesnél sosem lehet következetlenségre vagy pontatlanságra gondolni, azt hiszem, ez esetben arról lehet szó, hogy tanulmányának ebben a részében a görögségben általános életelvnek tekintett kalokagathia prioritását akarta érzékeltetni. Mert ahogy ez -bár jóval későbbi munkáiból, elsősorban - a Szimbolika-Evologika (1974), Jel és mozdulat (1974) vagy A tánc az emberi test beszéde (1976) c. írásaiból egyértelművé válik, a korai egymásnak való megmutatkozás külön tanulmánysorozat tárgyává lesz, mely a mozdulatot kifejezésként - közlésként, miáltal a másokkal való kommunikációnak is alapvető eszközeként láttatja. A kommunikáció során eszméletcsere jön létre, két vagy több eszmélet(tartomány) találkozik és például a tánc hatására mozgósított emlékek és jövő „szintéziséneksûrítményének" talaján közös jelentést hoz létre: a hatás ebben rejlik.

$\mathrm{Az}$ idézetben feltűnő műszer- és géphasonlat Dienesnél másutt is gyakran előfordul. Ez a metafora, korának egyik (futurista) toposza, ${ }^{13}$ Dienes rendszerében azonban kissé ellentmondásos, ha a mindvégig centrális testlélek viszonyra gondolunk. Pedagógiai jegyzetében is hangsúlyozottan arról beszél, hogy az ember „önmagát teremtó valóság”, és a „az emberi szervezet teljesen más, mint a gépezet’". (DIENES, 1925-27. 2016. 435, 433.) Sőt, ahogy írja: „A pedagógia [...] nem gépkezzelés. Az a pedagógus, aki növendékében a készülléket látja, az lehet jó dresszura ember, de nem lesz egyéni fejlesztô" (DIENES, 1925-27. 2016. 433.) és a nevelés egyik célja egy más, a szervesség gondolatkörébe illő fogalomhoz kötődik, az orgánum fejlesztéséhez. Ugyanebben a jegyzetben a nevelési eljárások közt külön kiemeli az egyéni különbségekre épülő (a különbségeket a Galenus féle négyes rendszerben értelmezi: szangvinikus, melankolikus, kolerikus, flegmatikus), illetve az evolúciós nevelést. Ez utóbbit a Nagy László kutatásai alapján meghatározott fejlődési szakaszokkal illusztrálja.

Másutt a Bergsonnal folytatott beszélgetésekre hivatkozva a pedagógiát úgy definiálja mint a személyiséget formáló eszméleti lét tényezőire való hatást. A pszichológia pedagógiai alkalmazásával arra jut, hogy a személyiséget alapvetően meghatározó múlt nem befolyásolható, a „személyiség anyagi tengelyéül szolgáló és reflexológiai értelemben vett motorikus készenlét' (DIENES 1925-30,1.) viszont igen. Ez azt jelenti például, hogy a mozdulatmúvészeti gyakorlatokkal rendezni lehet a „cselekvő gépezet” múködését (pl. befolyásolni lehet a reflexívek zavarát), leküzdhető a félénkség, vagy felszabadíthatók az eszmélet elnyomott emlékei, a gátló tudatalatti tartalmak. Dienes értelmezésében a betegség abból ered, hogy az

13 Madzsar Alice-nál és Szentpál Olgánál számos mozdulatprodukció témája is a gépember, vagy az elgépiesedett ember. 
eszmélet nem képes a cselekvéshez megfelelő emlékeket mozgósítani. (Egyébként több helyen is utal arra, hogy a mozdulatmúvészet megismerésre, diagnosztikai és terápiás célra egyaránt hasznosítható.)

\section{Tér és idő}

Visszakanyarodva a Brandenburgnak írt levélben jelzett mozdulatalapú orkesztika rendszerre, az alkotás-kifejezés térben és időben történik. „A mozdulat három határozmányú valami. Térben van, idóben van és mond valamit. Kifejez: A mozdulat-iskola tehát három feladat megoldását foglalja magában: uralkodás a téren, az idön és a jelentésen." (DIENES, 1918, 2016. 209-210.)

Mindez Dienes első rendszerében a plasztika, a ritmika és a mimika együttesében valósult meg, az egyes területek kidolgozásában tanítványainak is aktív szerep jutott, az iskola - a korabeli kísérleti lélektan szóhasználata szerint - egyfajta „laboratóriummá” lett. A mimika különböző műfaji kísérletekhez vezetett, melynek során Dienesnek a mozdulat és a beszéd, (pl. költészet), illetve a mozdulat és a zene viszonyát is tisztáznia kellett.

A levél szerint a tudatos térhasználat ebben az időben az egyensúlyt, a mozdulatok formáinak és rendjének tudatában azok harmonikus térbeli elhelyezését fedte. Az 1917-1918. évi tananyagot - a nyilván még meglévő eredeti jegyzetek alapján - az 1969-ben kelt Orkesztika 1912-1918. c. írásában Dienes részletesen is leírja. A plasztikai gyakorlatok a testhelyzetrehelyzetváltoztatásra és a test elmozdulásaira vonatkoznak (pl. a felső test, karok rajzai lépó és szökellő elmozdulással, előgyakorlatok a lendülethez, lendület különböző karmozdulatokkal, futás, szökdelés, lendülés egyoldalú és kétoldalú hangsúlyozással, lebegő járás szökdelésig stb.).

A zenéhez legközelebb álló ritmika időtagolás, de egyben tértagolás is, hiszen a különböző ritmusokra előadott mozdulatok más-más térben zajlanak, más-más teret hoznak létre. A görög verslábakra, illetve a zenére (gyakran a kortárs zenére, pl. Bartók) épített ritmikai stúdiumok a klasszikus verslábak „megtornázásától” - a többszólamú orchémákig (mozdulatmű, táncmú) terjedtek.

Ebben a korszakban Dienes a dinamikát (erô), mint rendszeralkotó tényezőt nem említi, az majd csak az 1920-as években keletkezett, nem mindig pontosan datálható- tanulmányaiban jelenik meg, legtisztább formában a Ritmika fejezeten belül a Dr. Dienes Valéria orkesztikai rendszere c. összegző munkájában (1929a). Visszaemlékezéseiból úgy tünik azonban, hogy a dinamika, „erőadagolásnak” is nevezve az Új Iskolában, a Kapás utcai orkesztika tanfolyamon és a Notre Dame 
de Sionban, vagyis 1923-ban és 1924-ben már óráinak szerves része volt. (FENYVES 2005, 73-76.)

A mimika mint jelentéstan, a későbbi rendszerben Babits javaslatára a szimbolika elnevezést kapta. Az orkesztikai tanulmányoknak ezt a szintjét Dienes elsősorban azoknak a tanítványainak ajánlotta, akik múvészi vagy tanári pályára készültek. A növendékek számára ez a tánckompozíciók elsajátítását jelentette, ismerkedést a különböző műfajokkal, amelyek a kifejezés eltérő lehetőségeit reprezentálják. A mimika „,...] Nem arjáték, hanem a testjáték, az egész, test vissz̧hangzása, a belsö világ kifejezni valója. Ebben az osztályban költeményeket és zenét interpretálunk mozdulatokekal és célunk végigmenni az emberi érzések minden skáláján. A növendékeek maguk is hoznak apróbb kompozició-gyakorlatokat ösztönsz̨erü mimikájuk érvényesitése kedvéert." (DIENES 1918, 2016, 210.)

A műfajok kapcsán felmerül a költészethez és a zenéhez való viszony, tágabban a mozdulat autonómiájának kérdése. Mert vannak olyan műfajok, (pl. ornamentika) melyek tisztán illusztrációk, nem haladják meg pl. a zene térbe való rajzolásának a szintjét ${ }^{14}$, míg mások azon túljutva hangulatot, történetet stb. táncolnak el. Dienes ekkor a legmagasabb szintnek a pantomimet tekinti, melyben a ritmika ugyan még mérvadó, de a mozdulat felszabadul és „korlátlanul formálható kifejező eszközzé” lesz. (DIENES 1918, 2016, 212.) „A feladat megtalálni számtalan lehetöség közül azt a ritmusmegjátszást, ami a jelentést legjobban visszaadja. Ez az a szabadság a ritmusban és büség a hangulatokban, amit az orchesztikai komponálásban nélkeülözhetetlennek találok." - írja a levélben. (DIENES 1918, 2016, 214.) A levelet a mozdulatírás, azaz az orcheográfia ismertetésével zárja.

Néhány évvel későbbi írásaiban a mozdulat általi kifejezés egyre inkább leválik a zenéről és a Dr. Dienes Valéria orkesztikai rendszere c. tanulmányban - bár a jövőre vetítve- a mozdulat autonómiája, primátusa fogalmazódik meg. „A tisz̨ta mozdulatkompozíció, mely nem interpretál más müvészi forma szerint, csupán a müvészet általános törvényeinek van alárendelve. Mozdulatmüvészetünk nagy elmaradottsága miatt hasznosak és szü̈kségesek a zenétöl és szövegtöl való kölcsönzések, de a végleges cél mégis az önálló mozdulatkomponálás a mozdulatnak sajátos igényei, sajátos értékelései, sajátos tematikája szerint, melyek mind hosszú tapasztalatok árán világosodnak majd meg elöttünk. Kell egy tematikának kifejlödnie és a mai kezdetleges állapotából kibontakozni, mely [...] nem puszta idót mintáz a maga formaszerüségével, mint szöveg és a zene, hanem a tér-idôt (kiemelés-

\footnotetext{
${ }^{14}$ Dienes számára a zene táncos illusztrálását Dalcroze testesítette meg, s bár sokra tartotta, mint zenészt, úgy vélte Dalcroze nem jutott tovább a zene rajzolásánál, és még abba sem mindig találta meg a ritmusnak megfelelő mozgásformát. Ennek a véleményének még a Brandenburghoz írt levelében is hangot adott.
} 
B.A.), aminek mintázására nincsen más müvészi nyersanyagunk, mint a mozdulat." (DIENES, 1929a, 45.)

\section{Összegzés}

A mozdulatrendszer vázlatos ismertetésével folytonosságot sugallva, helyenként kiléptem az 1910-es évekből, s ez elfedi azt a szakadást, amit Dienes kényszerű emigrációja okozott. Jóllehet Dienes Detre Szilárdnak és Mirkovszky Máriának címzett bécsi levelei is számos adalékot szolgáltatnak arról, hogyan gondolkozott a mozdulatművészetről, elméleti jellegű tanulmányokat az 1920-as évek közepéig-végéig nem írt. Így az orkesztika tudománya és az iskola is kétszer született, 1917-ben és (az utóbbi) 1924ben. (FENYVES 2005, 73.)

Visszatérve az orkesztika első szakaszához és a már többször idézett levélhez, felmerül a kérdés, hogy mi vezethette Dienes Valériát arra, hogy levelet írjon Hans Brandenburgnak? Mivel Brandenburg könyve volt az első összefoglaló mű az európai és amerikai modern tánc irányzatairól, Dienes szándéka nyilvánvalóan az lehetett, hogy közremúködésével az orkesztika számára helyet teremtsen az európai modern tánc színterén. Ez a vágya sohasem valósult meg.

Az iskolának az 1918-19-es tanévben három bemutatója volt, az egyik egy szeptember végi tanévnyitó Táncmatiné. Előtte, szeptember 20-án, Dienes tanítványaival, Mirkovszky Máriával, Révész Ilussal és Markos Györggyel együtt maga is fellépett Belgrádban. Előadásuk a szeptember 15én nyílt belgrádi magyar képzőművészeti kiállításhoz kapcsolódott, és bár a hirdetés szerint jótékonysági célú mûsor volt, nem elképzelhetetlen, hogy összefüggésben állt a Károlyi-kormány delegációjának (Linder Béla, Jászi Oszkár, Hatvany Lajos, Bokányi Dezső és Csernyák Imre) Franchet d'Esperay francia tábornokkal folytatott novemberi fegyverszüneti tárgyalásaival. 1919 márciusában Dienes és tanítványai Bécsben szerepeltek, a bécsi Konzerthausban léptek fel. Ezzel tulajdonképpen az alig néhány hónapos „európai” karrier be is fejeződött. Az Osztrák-Magyar Monarchia megszűnt, a monarchia által alkotott szellemi-múvészeti tér is darabokra esett. Az I. világháborút követő években egy müncheni meghívás (1928) kivételével sem Dienesnek, sem tanítványainak nem voltak külföldi szereplései. A müncheni iskolalapítást és már a korrektúránál tartó, az orkesztika rendszeréről szóló írásának német nyelvű publikációját meghiúsította Hitler hatalomra jutása. Itthon anyagi okok miatt nem tudta könyvét megjelentetni, a II. világháború után néhány évvel pedig magát a múfajt is betiltották. Több, mint száz év elteltével az orkesztika Dienes 
Gedeon és Fenyves Márk ezirányú törekvései ellenére sem vált a nemzetközi tánctörténet részévé. Fenti vázlatommal magam is ezt hiányt kívántam nyomatékosítani.

Boreczky Ágnes előadását (melynek tanulmány-változatát a fentiekben közöltük) „élő környezetben”, 2019 telén a Múcsarnok „Rejtett történetek” című kiállításának megtekintését követően hallgatták meg a Kiss Árpád Műhely rendezvényének résztvevői. A kiállítás, melynek az előadó egyik kurátora, az európai s magyar „életreform-mozgalmak” történetét, nem kis részt e törekvések vizuális lenyomatát mutatta be, a mozgalom sajátosságainak megfelelően - jóformán egyedülállóan egy képzőmúvészeti múzeum gyakorlatában - igen nagy teret szentelve az „életreform” jellegzetes pedagógiai hajtásainak. Ebben a kontextusban kapott helyet a magyarországi mozdulatművészet nagy korszaka is, s köztük Dienes Valéria életműve.

Az előadást élénk beszélgetés követte. Mik voltak a vita csomópontjai?

- A mozgás esztétikai és filozófiai értelmezése, Bergson, a bergsonizmus szerepe. E körben felvetődött a kérdés: miért is szól keveset a filozófia a mozgásról, mozdulatról. Volt hozzászóló, aki a filozófia nyelvezetét, bizonyítási kényszerét vélte ennek fő okául. Mások a test keresztény felfogásával magyarázták, hogy a XIX. század végéig a test, a mozgás problematikája tabu alá került. Abban mindenki egyetértett, hogy az életreform-mozgalmak, a mozgásművészet igen sokat tett a test, a testről való gondolkodás felszabadításáért.

- Szó esett a mozgás, a mozdulat kiterjedéséről. Dienestől sem volt idegen a sport és számos más mozgásforma bevonása a rendszeralkotásba, sőt az eszméletet, a „szellem mozgását” is ehhez kapcsolta.

- A tanulásfelfogásról, a mozgásból induló motiváció és a deduktív gondolkodás feszültségéről kiéleződött a vita. Miközben például Kiss Endre messzemenôkig elismerte, hogy Dienes mozgáskoncepciójából lehet transzfereket levezetni, a „gondolati ökonómia", a fogalmak világa azonban kihagyhatatlan, megkerülhetetlen. Az előadó védte „hősét”, mivel a hiányoltak szerinte mind benne vannak az eszmélet fogalmában. Az ismeretelmélet és a pszichológia határterületeire terelődött a vita e kérdésben. A kisgyermeknevelők, így a megszólaló Villányi Judit is sokat tudnak a mozgásfejlődésből kiinduló sokoldalú fejlesztésről. 
Sándor Ildikó, a néprajztudós Ong kulturális antropológiai szempontú könyvének tanulságait ecsetelte az írásbeliségrôl és a szóbeliségről, illetve a kétféle kultúrában élő közösségek gondolkodásmódjáról.

- A holisztikus vagy mozdulatközpontú személyiségkép vélt vagy valódi alternatívájáról is élénk vita zajlott. Forrai Judit Pető Andrásra hivatkozott: a holisztikus megközelítésben a mozgás és annak ritmusa segít a bénult test mozgásjavításban. Míg Dienes a mozgás, az egyik legkifejezőbb kommunikációs csatorna felól indult a személyiséghez, addig Pető és Kodály a személyiség fejlesztéséhez használta a mozgást. Petőnél és Kodálynál egyaránt ritmusra léptek a gyerekek, de Kodály az ének mellé tette ütemvezetônek a járást, míg Petô a ritmust tette a járáshoz. Ugyanazokat az eszközöket használták más célok érdekében.

- A beszélgetés az identitásválságok kérdésének tárgyalásával teljesedett ki. Az előadó arról kívánta meggyőzni a vitázókat, hogy a „filozófusból táncossá válás”, s a táncosból pedagógussá válás nem volt váltás Dienes életmúvében. Véleménye szerint a dolgok összetartozása a gondolat genezisében már benne volt.

- A vitában szó esett Dienes vallásos megtéréséről is. Egyetértés volt abban, hogy nem a forradalmak utáni kurzusváltás vezette Dienest a katolicizmushoz, a századelő progresszív világnézetének feladásához. Elhangzott, hogy az életreformerek, a mozdulatművészek világától egyébként nem volt idegen a miszticizmus, például Madzsar Aliz és Szentpál Olga is tartottak szellemidéző szeánszokat. De Dienes váltása más volt. Ehhez figyelembe kell venni az életút traumáit, a századelő utópiáinak tragikus összeomlását, férje emigrációját, s egyben új kapcsolatát, magzata elvesztésének traumáját. Nem csodálkozhatunk Dienes idegösszeroppanásán. Egyedül maradt. Ami vízióit múködtette: széthullott, ebben a nagy veszteséghalomban kínálkozott számára kiútként a vallás. Ha ehhez hozzávesszük az asszimilált zsidóság útkeresését a katolicizmusban, egészen Radnótiig bezárólag, akkor sok mindent megmagyaráznak ezek a mozzanatok. Mindehhez még az is hozzátartozik, hogy Bécsben, ahol Dienes élt, illetve Ausztriában mindenképp a „fekete” képviselte a ,jobbat” a „barna és a fekete", azaz a nácizmus és a katolicizmus közti választásban.

- Szó esett arról is, hogy a mozgásmúvészet betiltása többfajta okra vezethető vissza a II. világháború után. Az új, magát 
racionalistának hirdető hatalomnak nem kellett, jobban bízott a néptánc ideológiai interpretációjában. Jóllehet a Gyermektáncok 50es években készült első tantervében búvópatakként kimutathatóak a mozgásmûvész elődök tapasztalatai, tudása, így pl. a Dalcroze gyakorlatok. De Dienes ekkor már azonban idős, visszaemlékezéseit írja. az életmú jelentős, alapozó munkái a nagy korszakban, 1912 és 18 közt keletkeztek. Ezek tudományos igazságaihoz mindvégig hủ maradt.

Forrai Judit összefoglalása szerint a XIX. században a fegyelmező társadalom skatulyákba zárta a módszereket, a tudományokat. Az életreform újfajta szabadságfokot adott az embereknek, lehetőséget, hogy az elhanyagolt test és a tudomány egységes egészbe kerüljön. A mozgás annyira közel áll a lélekhez, a gondolkodáshoz, a pszichikumhoz, hogy a mozgásművészet jó pedagógiai módszernek, igazi humánus szemléletnek bizonyul. Széles látókört, új életszemléletet biztosít, kiszakít a skatulyákból. Elismerte, amikor valami új születik, akkor mindig vannak túlhajtások. A társadalom fegyelmező ereje azonban megmutatja a középutat, azt, hogy mennyit lehet a nóvumokból felhasználni. Forrai szerint abszolút pedagógus az, aki egy újfajta felszabadító lehetőséget hoz a gyereknevelésbe. Ilyennek látja Dienes Valériát is.

(A jegyzetíró ezúton mond köszönetet Gegus Ildikónak, aki videofelvételen rögzítette a Kiss Árpád Múhelynek Dienes Valériának szentelt beszélgetését, s így lehetőség nyílott a vita tanulságainak összegzésére.)

\section{Felhasznált irodalom}

BORECZKY Ágnes-FenYVES Márk (2017): Dienes Valéria bécsi évei és az Orkesztikai Iskola In: Németh András- Vincze Beatrix (szerk.) Továbbéló utópiák - magyar életreform törekvések és nemzetközi recepciós hatások, Budapest, Gondolat, 122-140

Brandenburg, Hans (1913, 1915, 1917, 1921): Der moderne Tan₹, München DiENES Valéria (1918): Levél Hans Brandenburgnak, In: Fenyves MárkDienes Valéria-Dienes Gedeon: A Tánc reformja - a mozdulatmúvészet vonzásában, Budapest, Orkesztika Alapítvány 2016, 207-217. 
DIENES Valéria (1924): Bergsonizmus az iskolában, In: Fenyves MárkDienes Valéria-Dienes Gedeon: A Tánc reformja- a mozdulatmúvészęt vonzásában, Budapest: Orkesztika Alapítvány, 2016, 335-342.

DIENES Valéria (1925-26): Pedagógiai-jegyzet, In: Fenyves Márk-Dienes Valéria-Dienes Gedeon: A Tánc reformja- a moẓdulatmüvészet vonzásában, Budapest, Orkesztika Alapítvány, 2016, 433-456.

DIENES Valéria (1925-30 között): Metafizika és mozdulatkultúra az. individuálpszichológiai szolgálatában, a-dvh-list00032-d_1 MOHA Mozdulatművészeti Gyüjtemény (Orkesztika Alapítvány - MOHA Mozdulatművészek Háza - Magángyűjtemény)

DiENES Valéria (1929a): Dr Dienes Valéria orkesztikai rendszere, a-dvhlist00002 MOHA - Mozdulatművészeti Gyüjtemény (Orkesztika Alapítvány - MOHA - Mozdulatművészek Háza - Magángyűjtemény)

DiENES Valéria (1929b): Mozdulatmúvészet, a-dvh-list00032 MOHA Mozdulatművészeti Gyűjtemény (Orkesztika Alapítvány - MOHA Mozdulatmúvészek Háza - Magángyüjtemény)

DiENES Valéria (1930): Mozdulatkultúra 1930 In: Fenyves Márk-Dienes Valéria-Dienes Gedeon: A Tánc reformja- a mozdulatmúvészet vonzásában, Budapest: Orkesztika Alapítvány 2016, 311-329.

DiENES Valéria (1969): Orkesztika 1912-1918. Raymond Duncannál. Kézirat. dvh-list00043 MOHA - Mozdulatmúvészeti Gyüjtemény (Orkesztika Alapítvány - MOHA - Mozdulatmúvészek Háza Magángyüjtemény)

DiENES Valéria (1970 körül): Táncfüzet részlet. In: Fenyves Márk-Dienes Valéria-Dienes Gedeon: A Tánc reformja- a mozdulatmúvészet vonzásában. Budapest: Orkesztika Alapítvány 2016, 107-110.

DIENES Valéria ( 1974-1976): Életrajzi vázlatok. Kézirat. EDAR DVHrendezetlen spirálfüzet- még leltári szám nélkül - MOHA MOZDULATMUUVÉSZETI GYÚJTEMÉNY (Orkesztika Alapítvány MOHA - Mozdulatmúvészek Háza - Magángyújtemény)

Dienes Valéria (1974): Jel és Mozdulat, In: Fenyves Márk-Dienes Valéria-Dienes Gedeon: A Tánc reformja- a mozdulatmüvészet vonzásában, Budapest: Orkesztika Alapítvány, 2016, 121-128.

DIENES Valéria (1974): Szimbolika-Evologika. In: Fenyves Márk-Dienes Valéria-Dienes Gedeon: A Tánc reformja- a mozdulatmúvészet vonzásában, Budapest, Orkesztika Alapítvány, 2016, 129-167. 
DIENES Valéria (1976): A tánc az embertest beszéde... In: Fenyves Márk-Dienes Valéria-Dienes Gedeon: A Tánc reformja- a mozdulatmúvészet vonzásában, Budapest, Orkesztika Alapítvány, 2016, 169-190.

FENYVES Márk (2005 szerk.): Az. Orkesżtika Iskola története képekeben, Budapest, Orkesztika Alapítvány

FÜGEDI János (2013): A Lábán-kinetográfia a Szentpál Iskolában, In: (Beke László-Németh András-Vincze Gabriella szerk.) Mozdulat - a magyar mozdulatmüvészet a korabeli társadalom és müvész̨et tükrében, Budapest, Gondolat, 142-163 